PSYCHOLOGIA ROZWOJOWA, $2020 *$ tom 25 , nr 4, s. 77-99

doi:10.4467/20843879PR.20.028.13436

www.ejournals.eu/Psychologia-Rozwojowa

MARIA KIELAR-TURSKA i https://orcid.org/0000-0002-6543-7030

Instytut Psychologii, Akademia Ignatianum w Krakowie Institute of Psychology, Jesuit University Ignatianum in Krakow e-mail: maria.kielar-turska@ignatianum.edu.pl

ANITA DUPLAGA i https://orcid.org/0000-0002-6428-6795

Instytut Psychologii, Akademia Ignatianum w Krakowie Institute of Psychology, Jesuit University Ignatianum in Krakow e-mail: anita.duplaga@gmail.com

\title{
Umiejętność operowania wiedzą i wyższe funkcje poznawcze uczniów edukacji domowej
}

\author{
The Ability to Operate Knowledge and Higher \\ Cognitive Functions of Home Education Students
}

\begin{abstract}
The presented research examined the relationship between the use of knowledge, the development level of higher cognitive functions and the type of education. Research was conducted on two groups of third grade students: homeschoolers and public school students ( 28 children in each of the groups). Students were paired by sex and factors connected to the family environment. Ability to operate knowledge was tested by The original Reading Comprehension Test and the level of development of executive functions (inhibition, working memory, cognitive flexibility and planning) was measured by a set of tasks from Inquisit computer program. Results show that homeschoolers use and utilize their knowledge better than public school students. They comprehend meaning of words more efficiently, understand cause-effect relations better and use relations of superiority-inferiority more efficiently. However, the results connected with executive functions do not show any dominance of any of groups. Ability of inhibition and planning is similar for homeschoolers and public students. Public school students have higher level of memory development whereas homeschoolers dominate in the category of flexibility. The presented results are material for a discussion on the role of the educational system in the development of late childhood students. They can also be used to consider the assessment of the value of home education.
\end{abstract}

Keywords: education, homeschooling, inhibition, working memory, flexibility, planning, knowledge operating, reading comprehension

Słowa kluczowe: edukacja, edukacja domowa, hamowanie, pamięć, elastyczność poznawcza, planowanie, operowanie wiedzą, rozumienie tekstu 


\section{ZNACZENIE EDUKACJI W ROZWOJU CZLOWIEKA}

Edukacja jest jedną z podstawowych form aktywności człowieka obok zabawy i pracy. W rozwiniętych krajach współczesnego świata edukacja jest obowiązkowa, a dostęp do niej uznawany jest za jedno z podstawowych praw człowieka (Powszechna Deklaracja Praw Człowieka, 1948, artykuł 26). Uważa się, że pozytywne skutki edukacji można zaobserwować we wszystkich sferach życia. Badania (np. Hafer, 2017) pokazują, że kraje szybciej rozwijające się najbardziej intensywnie edukują swoje dzieci, a inwestycje w edukację pozwalają danemu krajowi wzbogacać się. Relacja między edukacją a jakością życia jest zatem obustronna. Zdaniem Stevena Pinkera (2018, s. 284) „Wzrost edukacji - (...) - to okręt flagowy postępu ludzkości”.

Zagadnienie edukacji jako czynnika rozwoju było tematem rozważań psychologów. Zwrócimy uwagę na klasyczne prace Lwa Siemionowicza Wygotskiego (1971a i b), Jeana Piageta (1977) i Erika Eriksona (1997).

Wygotski (1971a) przeprowadził dogłębną analizę relacji nauczanie-rozwój, a jej wyniki przedstawił w pracy Problem nauczania i rozwoju umystowego $w$ wieku szkolnym. Jego zdaniem ,dobre jest tylko takie nauczanie, przez które rozwój jest wyprzedzany" (s. 544). Nauczanie i rozwój nie są dwoma niezależnymi procesami. Relacja, jaka zachodzi między nimi, nie sprowadza się ani do postępowania nauczania za rozwojem, ani też do synchronicznego występowania obu procesów. Nauczanie powinno zachodzić w strefie najbliższego rozwoju. Inaczej mówiąc, nie należy uczyć na poziomie aktualnego rozwoju dziecka, a zatem uczyć je tego, co już osiągnęło, ani też uczyć je tego, czego jeszcze nie jest w stanie zrozumieć. Należy uczyć tego, czym dziecko jest zainteresowane, czym umie się długo zajmować i potrafi skorzystać z oferowanej mu pomocy, osiągając znaczące efekty. Wygotski (1971b) proponuje także formy nauczania odpowiednie dla różnych okresów rozwoju. I tak dla wczesnego dzieciństwa odpowiednie jest nauczanie spontaniczne, kiedy to dziecko uczy się tego, czego samo chce, a dorosły postępuje za zainteresowaniami i pragnieniami dziecka. Cały proces uczenia wywołany jest spontanicznością reakcji dziecka i uwarunkowany jest dominacją funkcji spostrzegania. Dla wieku przedszkolnego właściwe jest nauczanie spontaniczno-reaktywne, które najpierw związane jest z zainteresowaniami dziecka, a następnie z propozycjami nauczyciela. W tym okresie dziecko, ,robi to, co chce, ale chce tego, czego chce jego wychowawca" (s. 518). Uczenie w wieku przedszkolnym związane jest z rozwojem pamięci, wyobrażeń i twórczym działaniem dziecka. Z kolei dla okresu późnego dzieciństwa charakterystyczne jest uczenie reaktywne, pod kierunkiem nauczyciela. Taki rodzaj uczenia się jest możliwy dzięki rozwojowi dowolności procesów poznawczych: uwagi, pamięci, myślenia. Dzięki temu osiągnięciu rozwojowemu możliwe staje się podejmowanie przez dziecko podawanych przez nauczyciela zadań i podążanie za jego wskazówkami.

Piaget (1977) w latach siedemdziesiątych dokonał syntetycznego podsumowania treści, metod, czasu i celów kształcenia oraz ich krytycznej oceny. Wskazał również na kierunki działań zmierzające do przeobrażenia szkoły, opierając się na wynikach studiów z zakresu psychologii rozwojowej. Uczenie, zdaniem Piageta, musi uwzględniać tempo rozwoju ucznia i być nastawione na kształcenie jednostek zdolnych nie tylko do powielania, ale i do wytwarzania oraz tworzenia. Proponowane przez Piageta zmiany w edukacji dotyczą stosowania w nauczaniu metod aktywnych prowadzących do odkrywania każdej prawdy na nowo, co wiąże się z realizowaniem w nauczaniu zasady: rozumieć to znaczy odkrywać przez ponowne odkrycie. Ważne jest przygotowanie uczniów do eksperymentowania. W nauczaniu korzystne jest wychodzenie od klasycznych pojęć i stopniowe modyfikowanie ich w kierunku pojęć współczesnych w celu ułatwienia przyswojenia nowych pojęć. Postępująca specjalizacja skłania, zdaniem Piageta, do interdyscyplinarnego powiązania różnych dziedzin wiedzy, a to prowadzi do opracowania przedmiotów szkolnych z nowych punktów widzenia, a także do przygotowania nauczycieli do realizowania wprowadzanych zmian. 
Przypominamy także zaproponowaną przez Erika Eriksona (1950/1997) koncepcję rozwoju człowieka w biegu życia. Zdaniem E. Eriksona rola edukacji w rozwoju człowieka zaznacza się najwyraźniej w okresie późnego dzieciństwa. Wówczas staje się ona źródłem rozwoju. Późne dzieciństwo jest okresem, w którym dziecko zostaje włączone w rozwiązywanie wielu pozaosobistych zadań i staje przed koniecznością opanowania wielu umiejętności. Jest gotowe podejmować zadania, które wykraczają poza zwyczajną zabawę. Poprzez rozwiązywanie zadań dziecko rozwija umiejętność planowania, przewidywania; czerpie przyjemność z ukończenia pracy, która wymaga wytężonej uwagi i wytrwałości. W ten sposób poznaje znaczenie pracowitości. Uczy się zyskiwać uznanie dzięki wykonywaniu różnych działań (liczenie, kopanie piłki, szukanie informacji w Internecie). Uczy się także posługiwania się różnymi narzędziami. Nauczycielami nie zawsze są dorośli. Bardzo często dziecko zdobywa wiedzę i umiejętności od rówieśników i równie często staje się nauczycielem swoich rodziców. Uczy się wykonywania zadań obok innych oraz z innymi. Zdobywa umiejętności komunikacji i współpracy. W okresie późnego dzieciństwa zagrożeniem dla rozwoju jest, zdaniem E. Eriksona (1997), brak nadziei na opanowanie nowych umiejętności, co prowadzi do poczucia niższości i zwątpienia. Wówczas dziecko uważa się za skazane na mierność i niedopasowanie do grupy rówieśników. Zagrożeniem może być także potraktowanie uczenia się jako obowiązku, co może prowadzić do ukształtowania ucznia jako konformistycznego i bezmyślnego wykonawcy zadań.

Spośród wielu różnych koncepcji edukacji dla prezentowanych w tym artykule rozważań interesujące będą te, które zwracają uwagę na rolę edukacji w stymulowaniu poznawczej sfery ucznia i przygotowywaniu go do korzystania z narzędzi kultury. Przypomnimy zatem podstawowe stwierdzenia dotyczące edukacji takich autorów, jak Jerome Bruner (2006), Basil Bernstein (1990), a także uwagi autorów raportów o stanie i kierunkach rozwoju edukacji przygotowywanych dla UNESCO przez Jamesa
W. Botkina, Mahdiego Elmandjrę, Mircea Malitzę (1982) i Jacquesa Delorsa (1998).

Zdaniem J. Brunera (2006) jednym z zadań edukacji jest przekazywanie narzędzi, które wypracowała kultura, a które pozwalają na wykraczanie poza aktualny poziom kompetencji ucznia i dostarczane informacje. Narzędziem pozwalającym zarówno na odbieranie, jak i transformowanie otrzymywanych informacji oraz na tworzenie nowych kategorii pozwalających w nowy sposób ujmować rzeczywistość jest język. Korzystając z uprzednio opanowanej wiedzy, uczeń może samodzielnie konstruować nowe kategorie znaczeń umożliwiające wychodzenie poza znane interpretacje rzeczywistości. Warto za Brunerem zaznaczyć, że takie efekty osiąga edukacja, którą cechuje partycypacyjność (uczeń jest aktywny, konstruuje swoją wiedzę), proaktywność (uczeń przejmuje inicjatywę, podejmuje decyzje), kooperatywność (uczeń wspólnie z nauczycielem i rówieśnikami poszukuje informacji, rozwiązuje zadania, co pozwala na postrzeganie danego problemu z różnych punktów widzenia) oraz nastawienie raczej na tworzenie niż przyjmowanie informacji w gotowej postaci. Edukacja musi przygotowywać ucznia do adaptowania się do zmian, bowiem „we współczesnym świecie - jak pisze Bruner (2006, s. 32) - zmiana jest normą". Uczniom należy dostarczać różnorodnych materiałów i narzędzi oraz zachęcać ich do podejmowania zarówno działań już znanych, jak i przekraczających aktualny poziom ich kompetencji. Uczenie powinno uruchamiać u ucznia proces odkrywania wyrażający się w selekcji informacji, tworzeniu hipotez, włączaniu nowych informacji. Edukacja jest, zdaniem Brunera, procesem wspomagania ucznia poprzez uczenie go używania narzędzi do konstruowania znaczeń. Proces ten wymaga interakcji z osobą, grupą, ale też z komputerem czy innymi narzędziami do komunikowania się. Kontakty mailowe mogą łączyć różne osoby, różne grupy, a także prowadzić do wytworzenia nowego obrazu świata, który może być dalej przekazywany. Edukacja przynosi zatem konsekwencje instrumentalne, które ujawniają się w późniejszym życiu. Ważne zatem jest zarówno opanowanie zestawu narzędzi proponowanych na danym etapie rozwoju 
cywilizacyjnego, jak i systemu symboli. Uczeń opanowuje i rozwija różne kompetencje, bądź to zalecane przez szkołę, bądź też związane z jego uzdolnieniami, ale wszyscy - zdaniem Brunera - powinni być kompetentni w zakresie relacji interpersonalnych. Szkoła odgrywa także ważną rolę w kształtowaniu tożsamości i poczucia własnej wartości. Uczeń doświadcza w szkole poczucia sprawstwa, co zapisuje się $\mathrm{w}$ jego pamięci autobiograficznej, a w przyszłości wpływa na aspiracje, zaufanie do siebie, optymizm. Ważną rolę odgrywa ocenianie przez nauczycieli, wpływając na poczucie własnej wartości ucznia. Nauczanie ma, zdaniem Brunera, zarówno charakter intrapsychiczny, bowiem oddziałuje na to, co dzieje się w umyśle ucznia, jak i interpersonalny, bowiem nauczyciel organizuje kulturowe konteksty edukacji, zapewniając dostęp do kulturowych narzędzi (Bruner, 2006, s. 101).

Na problem przygotowania ucznia do życia w zmieniającym się świecie zwrócili uwagę eksperci edukacji w latach siedemdziesiątych XX wieku (Botkin, Elmandjra, Malitza, 1982), wskazując na potrzebę rozwijania uczenia innowacyjnego, które ma charakter antycypacyjny, uczy przewidywania, przyjmowania nowości; opiera się na wyobrażeniach, dzięki czemu jest plastyczne; uwzględnia wartości, a przez to pokazuje, co w życiu jest ważne. Uczenie innowacyjne może przygotować ucznia na przyjmowanie $\mathrm{z}$ otwartością tego, co zdarzy się w przyszłości, na przyjmowanie nowości z zainteresowaniem, bez obawy przed nieznanym. „Dzięki antycypacyjnemu uczeniu się przyszłość może wkraczać w nasze życie jako przyjaciel, a nie zaś jak włamywacz" (s. 58) - stwierdzają autorzy. Natomiast występujące często w szkole uczenie zachowawcze dobrze przygotowuje do orientowania się i funkcjonowania w znanej rzeczywistości. Takie uczenie dotyczy opanowania czynności rutynowych, przyswojenia reguł, praw, zasad. Coraz częściej przekonujemy się, że uczenie zachowawcze, będąc użytecznym, okazuje się zdecydowanie niewystarczające do życia w zmieniającym się szybko świecie.

Zdaniem Basila Bernsteina (1990) szkoła oparta na układzie aktów komunikowania zapewnia ciągłość jakiejś odmiany społecznej egzystencji oraz uformowanie odpowiednich struktur mentalnych. Edukacja sprzyja budowaniu poznawczej reprezentacji świata, w czym istotną rolę odgrywa język, a zwłaszcza proces przypisywania znaczeń.

Odbywający się w szkole dyskurs obejmuje związane z kontekstem historycznym przekazywanie treści z uwzględnieniem wieku uczniów. Dyskurs edukacyjny składa się z trzech procesów: przekazywania, przyswajania i oceniania, którymi rządzą odpowiednio reguły dystrybucyjne (regulujące zakresy tego, co związane jest $z$ odtwarzaniem, i tego, co związane jest $\mathrm{z}$ tworzeniem; pozwalają ujmować to, co wyobrażalne i to, co niewyobrażalne), reguły rekontekstualizacyjne (które ustanawiają ład i uporządkowanie dyskursu pedagogicznego) oraz reguły oceniania (związane z praktyką pedagogiczną). W dyskursie pedagogicznym przekazywane są treści wybrane $\mathrm{z}$ danej dziedziny wiedzy i uważane za ważne społecznie. Przyswojenie tych treści przez ucznia jest oceniane.

Przywiązując wagę do procesów komunikowania się, które zachodzą w rodzinie i w szkole, B. Bernstein (1990) zaproponował koncepcję dwu systemów komunikowania się: za pomocą kodu ograniczonego (język publiczny, zamknięty system komunikowania się) i kodu rozwiniętego (język formalny, otwarty system komunikowania). Stosowanie danego kodu wiązał z uwarunkowaniami socjoekonomicznymi środowiska, w jakim jednostka żyje. Otwarty system komunikowania się ułatwia wchodzenie w kontakty z osobami pochodzącymi z różnych grup społecznych, używającymi różnego typu języka. W otwartym systemie komunikowania się uczestnicy posługują się językiem, który cechuje bogata składnia, bogactwo słownictwa odzwierciedlające bogactwo znaczeń, formułowanie sądów ogólnych, problematyzacja, wyrażanie uzasadnień i przekazywanie wartościowania. Natomiast zamknięty system komunikowania się może stanowić barierę dla kontaktów ucznia z nauczycielami i rówieśnikami w szkole. Zamknięty system komunikowania cechuje ubogie słownictwo, uboga składnia, wypowiadanie sądów o zdarzeniach, bez wartościowania, wyrażania uzasadnień, 
uogólniania. Szkoła może stanowić dla ucznia miejsce do rozwijania swego kodu językowego przez uczestniczenie w sytuacjach komunikacyjnych związanych $\mathrm{z}$ otwartym systemem komunikowania się.

Umiejętność komunikowania się została oceniona przez ekspertów (Delors, 1998) jako podstawowa kompetencja społeczna, której rozwijanie jest jednym z czterech podstawowych zadań szkoły. Zadanie „uczyć się, aby działać” wymaga nie tyle przekazywania zrutynizowanej praktyki, co rozwijania różnych kompetencji, wśród których ,najważniejsza staje się umiejętność porozumiewania się" (s. 90). Autorzy raportu stwierdzają: „Rozwój usług zmusza więc do kultywowania zalet, które niekoniecznie zawdzięczamy tradycyjnemu kształceniu, a które polegają na zdolności nawiązywania trwałych i skutecznych relacji między jednostkami”. Nabywanie kompetencji komunikacyjnej związane jest także z realizowaniem innych zadań, a mianowicie „uczyć się żyć wspólnie”, czyli realizować wspólne projekty i być otwartym na inne grupy, inne osoby. Zadanie „uczyć się, aby wiedzieć" związane jest z opanowaniem narzędzi wiedzy, z otwarciem się na inne języki, inną wiedzę, co wymaga komunikowania się. Także zadanie edukacji „uczyć się, aby być”, związane z rozwijaniem wyobraźni i kreatywności, wymaga komunikowania się związanego z wymianą doświadczeń dziecka i dorosłego.

Eksperci oceniający edukację zwracają uwagę na potrzebę zanurzenia jej w ogólnej kulturze, co sprzyja otwarciu na różne obszary wiedzy, nowe rozwiązania technologiczne, a także na prezentację dorobku przeszłych i współczesnych pokoleń związaną $\mathrm{z}$ doświadczaniem przeżyć estetycznych, artystycznych, sportowych, naukowych, kulturalnych, społecznych. Ważną rolę w kształceniu wyobraźni i kreatywności odgrywa rewaloryzacja kultury oralnej.

Edukacja zakłada również ,naukę uczenia się przez ćwiczenie uwagi, pamięci i myślenia" (Delors, 1998, s. 87). Ćwiczenie procesów poznawczych staje się szczególnie ważne w XXI wieku charakteryzującym się zalewem migawkowych, szybko następujących po sobie informacji. Uczeń powinien ćwiczyć powstrzymywanie się od natychmiastowych, stereotypowych reakcji, ćwiczyć selekcjonowanie informacji do zapamiętania oraz doskonalić myślenie zarówno indukcyjne, jak i dedukcyjne.

Zdaniem ekspertów edukacja XXI wieku ma dostarczyć uczniowi „mapę złożonego i wiecznie niespokojnego świata i busolę umożliwiającą po nim żeglugę" (Delors, 1998, s. 85).

Podsumowując przywołane rozważania teoretyczne, stwierdzamy, że edukacja odgrywać może istotną rolę w rozwoju, jeśli będzie pozostawała we właściwym do niego stosunku. Zdaniem autorów przypomnianych stwierdzeń proces nauczania powinien zostać opracowany z uwzględnieniem aktywnej roli ucznia, który nie tylko przyswaja przekazywane przez nauczyciela informacje, ale też aktywnie je transformuje, czyniąc zdobywaną wiedzę własną, oraz tworzy nowe interpretacje rzeczywistości. Stymulującą funkcję względem rozwoju pełni edukacja w okresie późnego dzieciństwa, kiedy to procesy poznawcze nabierają cechy dowolności.

\section{FORMY EDUKACJI}

Zanim w XIX wieku wprowadzono obowiązkową edukację szkolną, powszechną formą uczenia była edukacja domowa. Taka forma uczenia stanowiła skuteczny sposób zapobiegania analfabetyzmowi (Budajczak, 2004). Początki edukacji domowej w Polsce sięgają XVIII wieku i związane są z okresem zaborów. Celem ówczesnej edukacji domowej było nie tylko wyposażenie ucznia w wiedzę o świecie i umiejętności akademickie, ale przede wszystkim wychowanie patriotyczne. Taka forma edukacji była realizowana zarówno w rodzinach arystokratycznych, szlachecko-ziemiańskich, mieszczańskich, jak i robotniczych i chłopskich, choć na różnym poziomie zorganizowania. Po pierwszej wojnie światowej wydano Dekret o obowiązku szkolnym (Dekret z dnia 7.02.1919), nakładając na rodziców obowiązek zadbania o edukację dzieci w formie edukacji szkolnej lub domowej. Po drugiej wojnie światowej możliwa była jedynie edukacja w formie zorganizowanej edukacji szkolnej; nałożono zakaz prowadzenia szkół prywatnych i eduka- 
cji domowej. Stopniowo pojawiały się szkoły prywatne, a po zmianie systemu ustrojowego państwa w 1989 roku powstało wiele szkół społecznych. Czas edukacji sformalizowanej wyraźnie wydłużał się i obecnie w Polsce trwa od 12 (szkoła podstawowa i średnia) do ponad 20 lat (wliczając studia magisterskie i doktorskie). Zdobywanie wiedzy o świecie jest współcześnie coraz bardziej dostępne dzięki rozwojowi technologicznemu i może być realizowane poza szkołą. Każdy użytkownik Internetu może zasadniczo bez ograniczeń korzystać online z dotychczas zgromadzonej wiedzy. Cywilizacyjne osiągnięcia w postaci sposobów przekazywania informacji i sposobów korzystania z nich okazały się wręcz niezbędne do realizowania procesu edukacyjnego $\mathrm{w}$ okresie pandemii, jaka nawiedziła świat w 2020 roku. Umożliwiły one nie tylko przekazywanie informacji, ale także zapewniły utrzymywanie kontaktów interpersonalnych, choć realizowanych w formie zdalnej.

Zainteresowanie edukacją domową pojawiło się w wyniku krytyki i wykazywania niedostatków edukacji szkolnej, co działo się nie tylko w Polsce. Zasady realizowania obowiązku szkolnego w formie edukacji domowej zostały w Polsce prawnie zapewnione ustawą w $1991 \mathrm{roku}^{1}$ (Wenklar, 2013). Z tej formy edukacji korzysta obecnie około 12230 uczniów, w tym na poziomie kształcenia podstawowego - 9672 uczniów (dane z 6.05.2020)². Warto zauważyć, że liczba dzieci korzystających z edukacji domowej w innych krajach sukcesywnie wzrasta (na przykład w USA; Ray, 2010), co sugerować może skuteczność i atrakcyjność tej formy edukacji ${ }^{3}$.

\section{ISTOTA EDUKACJI DOMOWEJ}

Edukacja domowa jest alternatywną formą kształcenia polegającą na uczeniu w środowisku domowym przez domowych edukatorów (Pilch, 2003). Jest to forma organizowania kształcenia i wychowania poza systemem szkolnym, w której rodzice przejmują odpowiedzialność za edukację swoich dzieci; edukatorami są rodzice wspomagani niekiedy przez dodatkowo zatrudnionych nauczycieli (Kupisiewicz, Kupisiewicz, 2009).

O edukacji domowej można mówić jako o ruchu społecznym opartym na edukacyjnych przedsięwzięciach rodziców dążących do zapewnienia dzieciom wartościowego wykształcenia i wychowania (Budajczak, 2004). Ruch ten jest odpowiedzią na krytykę i wykazywanie niedoskonałości sformalizowanej edukacji szkolnej (Głowacka, 2015).

Edukacja domowa odznacza się dowolnością sposobów nauczania oraz dostosowaniem do potrzeb i możliwości dziecka (Budajczak, 2004). Ponadto ta forma edukacji wyraźnie nawiązuje do pragmatyki życia codziennego (Wenklar, 2013).

Edukacja domowa może być także rozpatrywana jako styl życia rodziny, wpisany w jej codzienne funkcjonowanie. Ta forma edukacji polega na wspólnym, włączonym w codzienny rytm życia rodziny uczeniu się rodziców i dzieci. Edukacja domowa zakłada mobilny sposób zdobywania wiedzy, związany z wychodzeniem do bibliotek, ośrodków kultury, wystaw, parków, lasów oraz z regularnym uczestniczeniem przez dzieci w zajęciach tanecznych, plastycznych, językowych organizowanych w społecznych ośrodkach kultury (Wenklar, 2013).

\section{KIERUNKI BADAŃ NAD EDUKACJĄ DOMOWA}

Dotychczasowe studia nad edukacją domową dotyczyły z jednej strony znalezienia uzasadnienia dla prowadzenia edukacji domowej, a z drugiej pokazania korzyści, jakie niesie ta forma edukacji dla rozwoju ucznia.

Źródeł edukacji domowej należy upatrywać w niezadowoleniu rodziców z edukacji szkolnej, a przede wszystkim w krytycznej ocenie edukacyjnych umiejętności nauczycieli (Kaczan, Rycielski, Wasilewska, 2012). Stąd odrzucane jest nie tylko nauczanie w szkole publicznej, ale także w szkołach społecznych czy prywatnych. Innym powodem jest poczucie powinności rodziców w zakresie zabezpieczenia możliwości najlepszej edukacji dla swego 
dziecka, często postrzeganego jako wyjątkowe, a przynajmniej bardziej uzdolnione od rówieśników (Harding, 1997). Zindywidualizowanego do potrzeb dziecka sposobu nauczania nie zapewnia nauczanie zbiorowe (Lubienski, Puckett, Brewer, 2013). Z tego względu rodzice są gotowi przyjąć niepopularną, ale skuteczną drogę edukacji, jaką jest, ich zdaniem, edukacja domowa (Divoky, 1983). Jednakże od krytycznych ocen nie jest też wolne rozwiązanie w postaci edukacji domowej, które daje szansę daleko posuniętej indywidualizacji nauczania. Wątpliwości budzi przygotowanie rodziców do roli edukatorów. Stwierdza się jedynie, że ani status materialny rodziny, ani też ich wykształcenie nie mają istotnego znaczenia dla osiągnięć edukacyjnych ich dzieci (Ray, 1997). Nie bierze się jednak pod uwagę kompetencji pedagogicznych rodziców w roli edukatorów. Zwraca się jedynie uwagę na używanie bardziej zaawansowanego języka przez matki-edukatorki (Harding, Farrell, 2003). Odwołując się do koncepcji Richarda Rorty'ego (1993), można powiedzieć, że prawdopodobnie nauczanie w szkole nie w pełni jest w stanie realizować funkcję wyzwalającą w odniesieniu do każdego ucznia, zaś edukacja domowa, skupiając się na zaspokajaniu indywidualnych potrzeb dziecka, może mieć problemy z realizowaniem funkcji socjalizującej.

Wybór edukacji domowej wiąże się także z troską rodziców wyrażającą się zapobieganiem możliwym niekorzystnym wpływom edukacji szkolnej (Budajczak, 2004; Ray, 2009; Medlin, 2013) oraz z szukaniem bardziej bezpiecznego środowiska edukacyjnego, wolnego od przemocy i narkotyków (Ray, 2011).

Zdaniem Terry Hardinga (1997) o wyborze edukacji domowej decydują względy natury praktycznej (odległość od szkoły), przekonania religijne czy specjalne potrzeby edukacyjne dziecka. Poza powodami obiektywnymi ważne jest poczucie odpowiedzialności rodziców za edukację dziecka, ich zaangażowanie w proces nauczania oraz wspieranie rozwoju społecznego swoich dzieci. To właśnie motywacja, inicjatywa i zaangażowanie rodziców decydują o skuteczności edukacji domowej (Lubienski, Puckett, Brewer, 2013).
Jak wynika z wielu badań, edukacja domowa ma bardzo pozytywny wpływ na osiągnięcia szkolne dzieci. W badaniach amerykańskich stwierdzono wyższe wyniki w testach osiągnięć u uczniów klas 1-12 korzystających z edukacji domowej w porównaniu ze średnią krajową, a 1/4 uczniów edukacji domowej wyprzedzała w nauce o rok lub więcej swoich rówieśników z edukacji szkolnej (Rudner, 1999). Podobne wyniki przyniosły badania prowadzone w Wielkiej Brytanii - dzieci pięcioletnie uczące się w domu osiągały wyniki w nauce powyżej średniej krajowej (Rothermel, 2004). Inne badania amerykańskich uczniów klas IV, VII i VIII pokazały lepsze wyniki uczniów edukacji domowej w testach czytania, z zakresu matematyki, języka, nauk ścisłych i nauk społecznych (za: Harding, Farrell, 2003). Wykazano ponadto, że dzieci uczone w domu częściej postrzegają siebie jako dobrego ucznia (Tillman, 1995).

Stwierdzono wysoką aktywność środowiskową dzieci korzystających z edukacji domowej. Dzieci te uczestniczą w zajęciach poza domem (Medlin, 2013), uczęszczają na zajęcia grupowe (Tillman, 1995), są zaangażowane w działalność różnych grup (Budajczak, 2004). Okazało się, że możliwości nawiązywania kontaktów przez dzieci uczące się w domu są tak samo duże, a nawet większe niż dzieci objętych edukacją szkolną; wchodzą one w kontakty z wieloma osobami w różnym wieku spoza rodziny (Medlin, 2013).

Poziom uspołecznienia amerykańskich dzieci korzystających z edukacji domowej jest wyższy w zakresie komunikacji, socjalizacji i codziennych umiejętności praktycznych niż dzieci edukowanych w systemie szkolnym (Smedley, 1992). Stwierdzono również, że dzieci uczone w domu wykazują wyższą aktywność obywatelską (Smith, Sikkink, 1993) i rozwój zdolności liderowania na wyższym poziomie niż dzieci korzystające $\mathrm{z}$ edukacji szkolnej (Medlin, 2013). Okazało się ponadto, że edukacja domowa jest predyktorem uzyskiwania lepszych wyników na studiach (Catsambis, 1998), przyszłego zadowolenia z życia i satysfakcji z pracy (Lubienski, Puckett, Brewer, 2013). 
Zauważono również pozytywny wpływ edukacji domowej na rozwój różnych cech osobowości. Badania amerykańskie wykazały, że dzieci uczące się w domu częściej niż ich rówieśnicy szkolni mają pozytywny obraz siebie w zakresie wyglądu oraz rozwoju intelektualnego (Taylor, 1986). Cechuje je wyższa samoocena i wyższa asertywność (Shyers, 1992). Zauważono, że edukacja domowa sprzyja poczuciu zadowolenia z życia (Lubienski, Puckett, Brewer, 2013).

Pozytywna ocena skuteczności edukacji domowej w wielu sferach rozwoju dziecka niewątpliwie skłania rodziców do jej wyboru. Warto jednak zauważyć, że wyniki badań porównawczych nad skutecznością edukacji domowej i edukacji zinstytucjonalizowanej są niejednoznaczne, obciążone niedociągnięciami metodologicznymi. Badane grupy uczniów edukacji domowej są zwykle małe (Carlson, 2020), a rodzice zgadzający się na badania stanowią elitę edukacyjną (West, 2009). Warto zauważyć, że rodzice decydujący się na edukację domową bardziej inwestują w rozwój swoich dzieci. Istotnym czynnikiem w podjęciu decyzji o formie edukacji dzieci jest wykształcenie rodziców, którzy przyjmują rolę edukatorów (Lubienski, Puckett, Brewer 2013). Ponadto matki występujące $\mathrm{w}$ roli domowych edukatorek używają bardziej zaawansowanego języka i stawiają dzieciom więcej wymagań intelektualnych $\mathrm{w}$ porównaniu $\mathrm{z}$ nauczycielami $\mathrm{w}$ szkole (Harding, Farrell, 2003).

\section{BADANY PROBLEM}

W sytuacji zapotrzebowania na empiryczne dowody dotyczące wartości edukacji domowej dla rozwoju dziecka podjęłyśmy badania eksploracyjne w Polsce. W naszych badaniach chodziło o sprawdzenie powiązań umiejętności operowania wiedzą przez ucznia i jego możliwości poznawczych, wyrażających się efektami w zakresie wyższych funkcji poznawczych, zwanych funkcjami zarządzającymi (Hughes, 2011; Miyake i in., 2000), z formą edukacji, z której korzysta. Badania zmierzały do uzyskania odpowiedzi na następujące pytania:
- Czy występują różnice w umiejętności operowania wiedzą między badanymi grupami dzieci: korzystającymi z edukacji domowej i uczestniczącymi w edukacji szkolnej?

Przyjęłyśmy, że przejawami umiejętności operowania wiedzą są:

- ujmowanie relacji nadrzędności - podrzędności między elementami rzeczywistości,

- dostrzeganie podobieństw i różnic oraz

- odkrywanie relacji przyczynowo-skutkowych w tekstach.

- Czy występują różnice w poziomie rozwoju funkcji zarządzających dzieci z dwu różnych środowisk edukacyjnych?

Przedmiotem badania były cztery podstawowe wyższe funkcje poznawcze, odpowiedzialne za podejmowanie intencjonalnych i ukierunkowanych na cel zachowań, polegających na rozwiązywaniu problemów, a mianowicie: hamowanie, pamięć operacyjna, plastyczność poznawcza i planowanie (Hughes, Graham, Grayson, 2004; Jodzio, 2008, Miyake i in., 2000).

\section{METODA}

\section{Grupa badana}

Badania rozpoczęto od zebrania grupy uczniów edukacji domowej i uzyskania zgody od ich rodziców na prowadzenie badań. Dzieci korzystających z edukacji domowej, realizujących program klasy III, jest znacznie mniej niż dzieci uczestniczących w edukacji szkolnej, nie było zatem łatwo zgromadzić odpowiednio licznej grupy badanych. W literaturze prezentującej wyniki badań porównawczych osiągnięć uczniów edukacji domowej i edukacji zinstytucjonalizowanej zwraca się uwagę na brak równoważności w zakresie jakości środowiska rodzinnego i lokalnego dzieci z obu grup (Rudner, 1999). Jednocześnie zaznacza się, że lepsze wyniki uczniów edukacji domowej są uwarunkowane większymi predyspozycjami społeczno-ekonomicznymi rodziny (Sacks, 2007; Wrigley, 2011) oraz że rodzice decydujący się na edukację domową bardziej inwestują w edukację swoich dzieci (Ray, 2010). Z tych 
Tabela 1. Badana grupa

\begin{tabular}{|c|c|c|c|c|c|c|c|}
\hline $\begin{array}{l}\text { System edukacji/ } \\
\text { środowisko lokalne }\end{array}$ & 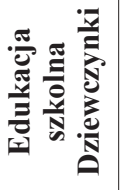 & 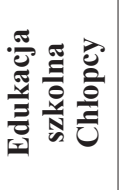 & 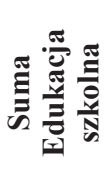 & 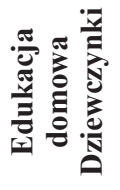 & 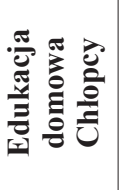 & 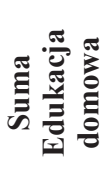 & Lącznie \\
\hline \multicolumn{8}{|l|}{ Środowisko lokalne: } \\
\hline - duże miasto & 6 & 6 & 12 & 8 & 4 & 12 & 24 \\
\hline - średnie miasto & 2 & 4 & 6 & 4 & 2 & 6 & 12 \\
\hline - małe miasto & 2 & 1 & 3 & 3 & 0 & 3 & 6 \\
\hline - wieś & 7 & 0 & 7 & 3 & 4 & 7 & 14 \\
\hline Suma & 17 & 11 & 28 & 18 & 10 & 28 & 56 \\
\hline \multicolumn{8}{|l|}{ Wykształcenie rodziców } \\
\hline - wyższe (matka i ojciec) & 15 & 10 & 25 & 17 & 8 & 25 & 50 \\
\hline - średnie (matka i ojciec) & 1 & 0 & 1 & 0 & 1 & 1 & 2 \\
\hline - mieszane (wyższe i średnie) & 1 & 1 & 2 & 1 & 1 & 2 & 4 \\
\hline Suma & 17 & 11 & 28 & 18 & 10 & 28 & 56 \\
\hline
\end{tabular}

względów warunek równoważności rodzin badanych dzieci pod względem społeczno-ekonomicznym starałyśmy się spełnić w naszych badaniach. Do badanych dzieci korzystających z edukacji domowej dobrano do pary uczniów edukacji szkolnej, kontrolując takie zmienne jak: płeć, etap edukacji (kl. III), środowisko lokalne (miejsce zamieszkania: miasto, wieś) oraz wykształcenie rodziców. Wszystkie dzieci pochodziły z rodzin pełnych i miały rodzeństwo. W badaniach wzięło udział 56 dzieci realizujących program III klasy szkoły podstawowej, w tym 28 uczniów uczęszczających do publicznej szkoły podstawowej i 28 uczniów korzystających z edukacji domowej. Rodzice badanych dzieci z obu grup mieli w większości wykształcenie wyższe (52 osoby) i sporadycznie średnie (4 osoby). Rolę edukatora w edukacji domowej pełniły w większości matki (26) i sporadycznie ojcowie (2). Strukturę badanej grupy przedstawiono w tabeli 1 .

\section{Narzędzia badawcze}

Do badania umiejętności operowania wiedzą wykorzystano autorski Test Rozumienia Czytanego Tekstu (TRCT). Inspiracją do stworzenia tego narzędzia był opracowany przez Jamesa Jenkinsa (1986) czworościenny model rozumienia. Zgodnie $\mathrm{z}$ tym modelem dla zrozumienia jakiegoś zagadnienia niezbędne jest:

- posiadanie wiedzy wyjściowej;

- umiejętność odczytania instrukcji, polecenia, zadania;

- znajomość strategii odczytania sensu zadania i umiejętność ich zastosowania w określonej sytuacji oraz

- struktura samego zadania (tekstu).

Do zbudowania narzędzia zwanego TRCT wykorzystano teksty z Wielkiej encyklopedii dla dzieci (Zasieczny, 1999), dotyczące czterech różnych obszarów wiedzy, a mianowicie: przyrody (góry), matematyki (liczby), historii 
(prawo) i języka (rodzaje języków). Do każdego tekstu o objętości 200-250 wyrazów przygotowano trzy rodzaje zadań badających:

- znajomość słów, w formie dobierania synonimów i antonimów (ZS);

- ustrukturowanie wiedzy w postaci pytań o znaczenie podanego terminu (UW);

- rozumienie relacji przyczynowo-skutkowych poprzez pytania o wyjaśnienie zjawiska opisywanego w tekście (RPS).

Test miał formę zadań wyboru poprawnej odpowiedzi z czterech propozycji w przypadku badania znajomości słów i rozumienia relacji przyczynowo-skutkowych. Oto przykłady zadań:

Znajomość słów (ZS):

Słowo, które znaczy to samo, co słowo wynaleźć, to:

$a$ - używać, b-robić, c-odkryć, d-pracować.

Słowo o przeciwnym znaczeniu do słowa często to:

a - wiele razy, b - co chwila, c-okazjonalnie, $\mathrm{d}$ - zazwyczaj.

Za każdą poprawną odpowiedź przyznawano 1 punkt. Za zadania z grupy ZS (8 zadań) można było uzyskać maksymalnie 8 punktów.

Rozumienie relacji przyczynowo-skutkowych (RPS):

Prawo ustanawiane jest po to, żeby:

a - móc karać ludzi,

b - pomóc ludziom żyć razem w pokoju,

c - uregulować kwestie, którymi nikt się nie zajmuje,

d - ludzie płacili kary.

Za każdą poprawną odpowiedź przyznawano 1 punkt. Za zadania z grupy RPS (12 zadań) można było uzyskać maksymalnie 12 punktów.

Badaniu ustrukturowania wiedzy (UW) służyły pytania otwarte. Na przykład: Co to jest lawa? Pytania tego rodzaju służyły poznaniu umiejętności dziecka dotyczących ustalania relacji między informacjami nadrzędnymi i podrzędnymi, czego wyrazem są sformułowania definicyjne zawierające rodzajowe określenia nadrzędne i specyfikujące, różnicujące określenia gatunkowe. Za pełną definicję przyznawano 2 punkty, za podanie jednego elementu: rodzaju nadrzędnego lub określenia gatunkowego - 1 punkt. Za zadania $\mathrm{z}$ grupy UW
(4 zadania) można było uzyskać maksymalnie 8 punktów.

Każde dziecko rozwiązywało 8 zadań badających znajomość słów, 12 zadań sprawdzających rozumienie relacji przyczynowo-skutkowych w tekście oraz 4 zadania badające ustrukturowanie wiedzy. W sumie każdy uczeń rozwiązywał 24 zadania, przyporządkowane do czterech tekstów, po 6 zadań do każdego z nich, i mógł uzyskać maksymalnie 28 punktów.

Wyższe funkcje poznawcze, zwane funkcjami zarządzającymi, takie jak: hamowanie, pamięć robocza, elastyczność poznawcza, planowanie badano za pomocą zestawu zadań z programu komputerowego Inquisit. Zadania te pozwalają testować poziom rozwoju funkcji zarządzających dzieci w okresie późnego dzieciństwa. W badaniach wykorzystano cztery rodzaje zadań badających różne rodzaje wyższych funkcji poznawczych. I tak do badania zdolności hamowania posłużono się zestawem zadań wykorzystującym efekt flankerów, który związany jest z koniecznością zahamowania narzucającej się reakcji w związku z pojawieniem się zakłócającego bodźca (flankera) (Child Flanker Task with Fish) (Eriksen, Eriksen, 1974; Cagigas i in., 2007; Salthouse, 2010; White i in., 2011; Johnstone, Galletta, 2012). Na ekranie wyświetlane są ciągi złożone $\mathrm{z}$ ikon ryb płynących w prawo lub w lewo. Zadanie badanego polega na naciśnięciu przycisku z zaznaczoną strzałką kierunkową, której kierunek jest zgodny z kierunkiem ustawienia ikony znajdującej się w środku szeregu. W badaniu zastosowano zestaw składający się z 80 prób. Miarą wykonania każdego zadania jest stosunek różnicy czasu reakcji na próby zgodne i czasu reakcji na próby niezgodne do czasu reakcji na próby zgodne, określany jako proporcjonalny koszt (Józefacka-Szram, 2014). Zgodnie z zaleconym wzorem obliczano koszt wykonania zadania dla każdego dziecka, a następnie obliczono średni koszt dla każdej z badanych grup.

Próby służące do badania pamięci roboczej wzorowane są na zadaniu Klocki Corsiego (Corsi Block Tapping Task: CBT lub Corsi Tapping Test: CTT; Kessels i in., 2000). Na 
ekranie wyświetlanych jest 9 niebieskich kwadratów, a w poszczególnych próbach zmienia się ich barwa (na żółtą), we wzrastającej liczbie i odmiennej kolejności z próby na próbę. W kolejnych próbach liczba zaznaczonych na żółto kwadratów zwiększa się o 1. Zadaniem dziecka jest odtworzenie liczby i kolejności pojawiających się na ekranie kwadratów. Za poprawne wykonanie wszystkich prób badany uzyskuje 81 punktów. Miarą wykonania testu jest liczba poprawnie wykonanych prób, z uwzględnieniem liczby i kolejności pojawiających się na ekranie zmienionych kolorystycznie kwadratów w każdej z nich.

Do badania elastyczności poznawczej służy Zmodyfikowany Test Sortowania Kart z Wisconsin (Modified Card Sorting Test: MCST; Cianchetti i in., 2007). W dolnej części ekranu umieszczone są 4 karty wzorcowe zróżnicowane pod względem koloru, liczby i kształtu elementów umieszczonych na karcie, zaś w górnej części ekranu pojawia się karta, którą należy dopasować do jednej z kart wzorcowych. Reguła sortowania kart podawana jest przez osobę prowadzącą badanie. Miarą rozwiązania testu jest liczba poprawnie wykonanych prób. Maksymalnie można zdobyć 48 punktów.

Zadanie służące do badania zdolności planowania stanowi modyfikację próby zwanej Wieżą z Londynu (Tower of London) (Shallice, 1982; Krikorian i in., 1994; Anderson i in., 1996; Schnirman, 1998; Berg, Byrd, 2002). Zadaniem osoby badanej jest utworzenie wieży według podanego wzorca poprzez przebudowanie modelu wyjściowego, stosując się do podanych zasad dotyczących rodzaju ruchów $\mathrm{i}$ ich liczby. Miarą wykonania testu jest liczba poprawnie wykonanych prób. W ocenie brano pod uwagę ostateczny pozytywny rezultat obliczany automatycznie w programie. Można było uzyskać maksymalnie 36 punktów.

\section{Procedura badania}

Badanie rozpoczynano od zadań sprawdzających funkcje zarządzające. Dzieci wykonywały zadania w programie Inquisit, na komputerze przenośnym osoby prowadzącej badanie. Przed każdym z zadań dziecko słuchało instrukcji czytanej przez badacza. Po potwierdzeniu jej rozumienia wykonywało zadanie. Następnie badane dziecko otrzymywało instrukcję do testu TRCT. Czytało tekst z danej dziedziny i udzielało odpowiedzi na przygotowane do niego pytania. W związku z tym, że w skład testu wchodziły cztery teksty, czynność tę powtarzano czterokrotnie.

Badania prowadzono w domu rodzinnym dziecka (w przypadku uczniów edukacji domowej) lub w szkole (w przypadku uczniów edukacji zinstytucjonalizowanej), czyli w naturalnym środowisku edukacyjnym dziecka. Czas badania wynosił około 40 minut.

Ponadto jedynie z rodzicami prowadzącymi edukację domową prowadzono rozmowę na temat wartości edukacji w życiu człowieka. $\mathrm{Z}$ powodu braku pełnego materiału $\mathrm{z}$ obu badanych grup nie przeprowadzono analiz porównawczych.

\section{WYNIKI}

\section{Umiejętność operowania wiedzą}

W zakresie trzech badanych zmiennych (znajomość słów, ustrukturowanie wiedzy, wyjaśnianie zjawisk), obrazujących umiejętność operowania wiedzą, stwierdzono istotne statystycznie różnice między badanymi grupami (tabela 2). Uczniowie edukacji domowej wykazali się lepszą znajomością słów (ZS), lepiej poradzili sobie z wyborem słów o znaczeniu bliskoznacznym i przeciwstawnym $(t=2.54, p=.014$, $d$ Cohena $=.89)$. W zakresie umiejętności formułowania definicji (UW), będącej wyrazem ustrukturowania posiadanej wiedzy, uczniowie edukacji domowej osiągnęli istotnie lepsze wyniki w porównaniu z uczniami szkół powszechnych $(t=2.27, p=.028, d$ Cohena $=.52)$. Odpowiedzi dzieci uczestniczących w edukacji domowej częściej zbliżały się do definicji pełnych, składających się z określenia nadrzędnego i cech gatunkowych. Dzieci uczone w domu osiągnęły też znacznie lepsze wyniki niż uczniowie szkolni w wyjaśnianiu zjawisk i rozumieniu zależności przyczynowo-skutkowych $(t=3.40, p=.001, d$ Cohena $=.67)$. 
Tabela 2. Statystyki opisowe i istotność różnic między grupami w odniesieniu do zmiennych mierzonych w teście umiejętności operowania wiedzą

\begin{tabular}{|l|c|c|c|c|}
\hline \multicolumn{1}{|c|}{ Grupy zadań } & $\begin{array}{c}\text { Edukacja } \\
\text { domowa }\end{array}$ & $\begin{array}{c}\text { Edukacja } \\
\text { szkolna }\end{array}$ & $\boldsymbol{t}$ & $\boldsymbol{p}$ \\
\hline Znajomość słów (ZS) & & & & \\
Średnia & 6.17 & 5.14 & 2.54 & $\mathbf{. 0 1 4}$ \\
Odchylenie standardowe & 1.41 & 1.62 & & \\
Min-max & $3-8$ & $2-8$ & & \\
\hline Ustrukturowanie wiedzy (UW) & 4.35 & 3.53 & 2.27 & $\mathbf{. 0 2 8}$ \\
Średnia & 1.56 & 1.10 & & \\
Odchylenie standardowe & $1-7$ & $2-5$ & & \\
Min-max & & & & \\
\hline Wyjaśnianie zjawisk (RPS) & 9.39 & 7.46 & 3.40 & \\
Średnia & 1.87 & 2.34 & & \\
Odchylenie standardowe & $4-12$ & $3-11$ & & \\
Min-max & & & & \\
\hline
\end{tabular}

Tabela 3. Liczba poprawnych odpowiedzi w zadaniach dotyczących podawania synonimów i antonimów

\begin{tabular}{|l|c|c|c|}
\hline & Edukacja domowa & Edukacja szkolna & Suma \\
\hline Synonimy & & & 53 \\
\hline fragment & 27 & 26 & 52 \\
\hline wynaleźć & 26 & 26 & 52 \\
\hline obecnie & 26 & 26 & 39 \\
\hline skłaniać & 25 & 14 & $\mathbf{1 9 6}$ \\
\hline suma & $\mathbf{1 0 4}$ & $\mathbf{9 2}$ & 19 \\
\hline Antonimy & 11 & 8 & 27 \\
\hline wiecznie & 16 & 11 & 35 \\
\hline często & 20 & 15 & 41 \\
\hline długo & 24 & 17 & $\mathbf{1 2 2}$ \\
\hline nowe & $\mathbf{7 1}$ & $\mathbf{5 1}$ & \\
\hline suma & & & \\
\hline
\end{tabular}

Znajomość słów sprawdzano testem synonimów i antonimów, a uzyskane wyniki przedstawiono w tabeli 3. Uczniowie obu grup dobrze radzili sobie $\mathrm{z}$ testem synonimów, odnajdując poprawnie równoważniki semantyczne takich słów jak: fragment, wynaleźć, obecnie. Pewną trudność sprawiło uczniom edukacji szkolnej słowo: skłaniać; jego poprawny odpowiednik znaczeniowy wybrała poprawnie jedynie połowa badanych. Natomiast wszyscy uczniowie edukacji domowej odnaleźli adekwatną odpowiedź. Trudność sprawiało wszystkim badanym 
Tabela 4. Rodzaje podawanych definicji zawierających wyjaśnienia znaczeń testowanych wyrazów (liczba odpowiedzi)

\begin{tabular}{|l|c|c|c|c|c|}
\hline $\begin{array}{c}\text { Rodzaje definicji/ } \\
\text { System edukacji }\end{array}$ & Pełna & $\begin{array}{c}\text { Określenie } \\
\text { nadrzędne }\end{array}$ & $\begin{array}{c}\text { Cechy } \\
\text { gatunkowe }\end{array}$ & $\begin{array}{c}\text { Odpowiedź } \\
\text { błędna }\end{array}$ & Suma \\
\hline Edukacja domowa & 32 & 14 & 46 & 20 & 112 \\
\hline Edukacja szkolna & 15 & 14 & 60 & 23 & 112 \\
\hline Suma & 47 & 28 & 106 & 43 & 224 \\
\hline
\end{tabular}

Tabela 5. Liczba poprawnych wyjaśnień podanych przez dzieci z obu systemów edukacyjnych

\begin{tabular}{|l|c|c|c|c|c|}
\hline $\begin{array}{c}\text { Tematyka tekstu/ } \\
\text { Rodzaj edukacji }\end{array}$ & $\begin{array}{c}\text { Przyroda } \\
\text { (góry) }\end{array}$ & $\begin{array}{c}\text { Historia } \\
\text { (prawo) }\end{array}$ & $\begin{array}{c}\text { Matematyka } \\
\text { (znak) }\end{array}$ & $\begin{array}{c}\text { Język } \\
\text { (rodzaje) }\end{array}$ & $\begin{array}{c}\text { Suma/ \% } \\
\text { (336) }\end{array}$ \\
\hline Edukacja domowa & 72 & 77 & 58 & 57 & $264(78,5)$ \\
\hline Edukacja szkolna & 57 & 53 & 45 & 42 & $197(58,6)$ \\
\hline Suma & 129 & 130 & 103 & 99 & $461(68,6)$ \\
\hline
\end{tabular}

336 - maksymalna liczba punktów możliwa do uzyskania przez każdą z dwu badanych grup dzieci (12 punktów x 28 dzieci)

168 - liczba punktów uzyskanych przez obie grupy badanych dzieci w danym obszarze tematycznym (3 punkty x 56 dzieci)

odnajdywanie słów o znaczeniach przeciwstawnych do takich słów jak: wiecznie, często, dtugo, nowe. Szczególnie trudne okazało się znalezienie antonimu do słowa wiecznie; najlepiej rozumiane było znaczenie słowa nowe.

Wyrazem ustrukturowania wiedzy było podawanie znaczenia słów w formie definicji zawierającej rodzaj nadrzędny oraz różnicę gatunkową. Pytano o znaczenia następujących słów o znaczeniach konkretnych: lawa, król, i o znaczeniach abstrakcyjnych: znak, porozumiewać się. W ocenianiu odpowiedzi badanych posłużono się definicjami zawartymi w Słowniku Języka Polskiego (Doroszewski, 1996). Wyniki dla obu badanych grup podano w tabeli 4.

Uczniowie korzystający z edukacji domowej częściej potrafili podać pełną definicję, zawierającą rodzaj nadrzędny i różnicę gatunkową, w porównaniu z rówieśnikami uczęszczającymi do szkół publicznych. Dla wszystkich badanych najłatwiejsze było podanie pełnej definicji znaczenia wyrazu król. Oto przykład: To osoba najważniejsza w kraju, która rządzi i wydaje prawa. Pilnuje, żeby $w$ kraju byt porzadek $i$ nic złego się nie działo (D).

Najrzadziej pełna definicja pojawiała się w przypadku drugiego słowa o znaczeniu konkretnym - lawa. Znaczenie tego wyrazu było przedstawiane poprzez wymienianie cech gatunkowych. Taka forma odpowiedzi była podawana przez uczniów obu badanych grup. $\mathrm{Na}$ przykład: Jest $w$ wulkanie, jest goraca, ma czerwony kolor $(\mathrm{Sz})$.

Definiowanie znaczeń wyrazów abstrakcyjnych sprawiało wszystkim badanym trudność, co często znajdowało wyraz w podawaniu odpowiedzi błędnych. Na przykład: Znak to taki znaczek (D), Znak to jest takie coś, gdzie jest coś narysowane albo napisane (Sz). Mniej trudności sprawiało podanie znaczenia drugiego wyrazu: porozumiewać się. Uczniowie edukacji domo- 
wej potrafili przedstawić znaczenie tego słowa w formie pełnej definicji (np.: Mówić do drugiej osoby, chociaż nie musza być dwie, może być więcej. Można się porozumiewać na przykład przez telefon, pisanie maili i tak dalej (D), zaś uczniowie edukacji szkolnej najczęściej podawali jedynie określenia nadrzędne (np.: mówić do kogoś (Sz)).

Wyrazem umiejętności wyjaśniania zjawisk były odpowiedzi na pytania wymagające wykrycia relacji przyczynowo-skutkowych w podanych tekstach. Oto przykłady pytań: Jak powstaje wyspa? Co to znaczy, że język się zmienia?

Wyniki liczbowe wskazujące na umiejętność wyjaśniania relacji przyczynowo-skutkowych przez badanych uczniów z obu grup przedstawiono w tabeli 5.

Dla obu grup dzieci łatwiejsze do zrozumienia okazały się teksty dotyczące przyrody (góry) i historii (prawo). Najwięcej trudności w zrozumieniu tekstu zauważono w przypadku tekstów dotyczących języka oraz matematyki. Tematy przedstawione $\mathrm{w}$ tych tekstach sprawiały trudność uczniom z obu badanych grup. W odpowiedzi na jedno z pytań do tekstu z matematyki (W jaki sposób pokazywana była liczba 30 w epoce kamienia?) uczniowie edukacji szkolnej byli skłonni wybierać dosłowne sformułowania $\mathrm{z}$ tekstu, będące błędnymi odpowiedziami (za pomoca cyfr rzymskich; za pomoca cyfr arabskich), a nie poprawną od-

Tabela 6. Wskaźniki wykonania prób z flankerami przez obie badane grupy oraz istotności różnic

\begin{tabular}{|c|c|c|c|c|c|c|c|c|c|}
\hline $\begin{array}{c}\text { Średni } \\
\text { koszt } \\
\text { Edukacja } \\
\text { domowa }\end{array}$ & $\begin{array}{c}\text { Średni } \\
\text { koszt } \\
\text { Edukacja } \\
\text { szkolna }\end{array}$ & $\boldsymbol{t}$ & $\boldsymbol{d z}$ & $\boldsymbol{p}$ & $\begin{array}{c}\text { Odch. } \\
\text { std. } \\
\text { Edukacja } \\
\text { domowa }\end{array}$ & $\begin{array}{c}\text { Odch. } \\
\text { std. } \\
\text { Edukacja } \\
\text { szkolna }\end{array}$ & $\begin{array}{c}\text { Levene'a } \\
\boldsymbol{F}_{(1, \mathrm{~d})}\end{array}$ & $\begin{array}{c}\boldsymbol{d f} \\
\text { Levene'a }\end{array}$ & $\begin{array}{c}\boldsymbol{p} \\
\text { Levene'a }\end{array}$ \\
\hline 05 & .08 & -1.5 & 54 & .126 & .07 & .08 & .27 & 54 & .602 \\
\hline
\end{tabular}

Tabela 7. Statystyki opisowe i istotność różnic dla prób badających pamięć roboczą

\begin{tabular}{|l|l|c|c|}
\hline \multicolumn{2}{|l|}{} & Edukacja domowa & Edukacja szkolna \\
\hline \multirow{2}{*}{ Klocki Corsiego - zdobyte punkty } & średnia & 29.78 & 36.85 \\
\cline { 2 - 4 } & \multirow{2}{*}{ minimum } & 9 & 9 \\
\cline { 2 - 4 } & maksimum & 54 & 54 \\
\cline { 2 - 4 } & $\begin{array}{l}\text { odchylenie } \\
\text { standardowe }\end{array}$ & 10.96 & 10.45 \\
\hline \multirow{2}{*}{ Istotność różnic } & $t=2.54$ & $d f=54$ & $p=.014$ \\
\hline
\end{tabular}


powiedź stanowiącą pewną modyfikację sformułowania przedstawionego w tekście (sformułowanie $\mathrm{w}$ tekście zawierające poprawną odpowiedź na pytanie: za pomoca 30 znaków i zmodyfikowane sformułowanie w teście: $z a$ pomoca pojedynczych znaków).

\section{Wyższe funkcje poznawcze}

Poziom rozwoju wyższych funkcji poznawczych sprawdzano za pomocą zestawu zadań z programu komputerowego Inquisit, oceniając hamowanie, pamięć roboczą, elastyczność poznawczą i planowanie.

Przejawem hamowania była umiejętność powstrzymywania się od narzucającej się reakcji wyznaczonej przez dane percepcyjne w zadaniu Child Flanker Task with Fish (np. ukierunkowanie obiektu zgodne z kierunkiem strzałki do naciskania), zaś wskaźnikiem hamowania była proporcja różnicy średniego czasu reakcji na próby niezgodne i na próby zgodne do średniego czasu reakcji na próby zgodne. Stwierdzono brak istotnych statystycznie różnic między badanymi grupami $(t=-1.55, p=.126, d$ Cohena $=-.41)$, co pokazuje, że żadna $\mathrm{z}$ grup nie potrzebowała więcej czasu na przezwyciężenie interferencji; uczniowie obu grup tak samo szybko i skutecznie poradzili sobie z wykonaniem prób, w których bodziec otoczony był flankerami.

Tabela 8. Statystyki opisowe i istotność różnic dla prób badających elastyczność poznawczą

\begin{tabular}{|l|l|c|c|}
\hline \multicolumn{2}{|l|}{} & Edukacja domowa & Edukacja szkolna \\
\hline \multirow{4}{*}{ MCST - zdobyte punkty } & średnia & 36.46 & 33.39 \\
\cline { 2 - 4 } & minimum & 26 & 21 \\
\cline { 2 - 4 } & maksimum & 43 & 39 \\
\cline { 2 - 4 } & $\begin{array}{l}\text { odchylenie } \\
\text { standardowe }\end{array}$ & 3.74 & 5.02 \\
\cline { 2 - 4 } & Istotność różnic & $\begin{array}{c}U=253.50 \\
Z=2.26\end{array}$ & $p=.024$ \\
\hline
\end{tabular}

Tabela 9. Statystyki opisowe i istotność różnic dla prób badających umiejętność planowania

\begin{tabular}{|l|l|c|c|}
\hline \multicolumn{2}{|l|}{} & Edukacja domowa & Edukacja szkolna \\
\hline \multirow{4}{*}{ Wieża z Londynu } & średnia & 30.39 & 29.57 \\
\cline { 2 - 4 } & minimum & 19 & 24 \\
\cline { 2 - 4 } & maksimum & 36 & 35 \\
\cline { 2 - 4 } & $\begin{array}{l}\text { odchylenie } \\
\text { standardowe }\end{array}$ & 3.51 & 2.83 \\
\cline { 2 - 4 } & Istotność różnic & $\begin{array}{l}t=.96 \\
d f=54\end{array}$ & $p=.340$ \\
\hline
\end{tabular}


Pamięć roboczą sprawdzano za pomocą zadania Klocki Corsiego, w którym miarą pamięci roboczej jest liczba punktów za poprawne odtworzenie ułożenia klocków na tablicy/ekranie. Okazało się, że wyższe wyniki uzyskali uczniowie szkół publicznych, a zaznaczająca się różnica w porównaniu z wynikami osiągniętymi przez uczniów edukacji domowej okazała się istotna statystycznie $(t=2.54, p=.014$, $d$ Cohena $=-.6485$ ).

Miarą elastyczności poznawczej był wynik uzyskany w zadaniu wymagającym umiejętności szybkiego przełączania kryterium klasyfikacji danych. Celowi temu służył Zmodyfikowany Test Sortowania Kart z Wisconsin.

Okazało się, że badane grupy różnią się między sobą, a wyższe wyniki uzyskały dzieci uczestniczące w edukacji domowej $(U=253.50$, $\left.p=.024, r_{g}=.51\right)^{4}$.

Miarą umiejętności planowania było zadanie zwane Wieżą z Londynu. Okazało się, że średnie wyniki uzyskane w tym zadaniu przez obie grupy były podobne $(t=.96, p=.340$, $d$ Cohena $=.25$ ).

W świetle uzyskanych wyników można powiedzieć, że mimo iż uczniowie obu grup pochodzą z podobnych środowisk lokalnych, zapewniających podobne środowisko rozwojowe, a ich rodzice legitymują się takim samym wykształceniem, to prezentują oni inny poziom rozwoju wyższych funkcji psychicznych. O ile tak samo dobrze kontrolują narzucające się reakcje, a więc dowolnie kierują swoją aktywnością i osiągają podobne wyniki w przewidywaniu swoich działań, to edukacja domowa wyraźnie sprzyja rozwojowi elastyczności poznawczej, zaś edukacja szkolna - ćwiczeniu pamięci operacyjnej.

\section{DYSKUSJA}

Wyniki zaprezentowanych $\mathrm{w}$ artykule polskich badań nad związkiem między poznawczym rozwojem dziecka w późnym dzieciństwie a systemem edukacyjnym, jakiemu podlega, wpisują się w stale obecny w literaturze nurt rozważań i badań empirycznych nad rolą edukacji w roz- woju. Przedstawione badania dotyczą związków między niektórymi aspektami rozwoju poznawczego a rodzajem edukacji, którego rozwojowa wartość jest dyskutowana. Większość badań dotyczących edukacji domowej pokazuje, że stanowi ona korzystne środowisko rozwojowe dla dziecka (Rudner, 1999; Rothermel, 2004). Amerykańskie badania (Boulter, 2017) porównujące wyniki osiągnięć akademickich uczniów korzystających z edukacji szkolnej lub domowej wykazały skuteczność edukacji domowej w zakresie wszystkich przedmiotów szkolnych i na każdym etapie kształcenia. Prowadzone przez nas badania dostarczają dowodowego materiału do dyskusji o wartości różnych form edukacjidomowej i szkolnej - dla rozwoju poznawczego dzieci okresu późnego dzieciństwa.

Nasze badania dotyczyły uczniów okresu późnego dzieciństwa, kiedy to, zdaniem Eriksona (1997), ważnym źródłem rozwoju jest edukacja. W okresie tym, jak zauważa Wygotski (1971a), dziecko jest wrażliwe na edukacyjne oddziaływania otoczenia, a znaczącymi społecznymi czynnikami rozwoju są nauczyciele i rówieśnicy. Rozwój dowolności procesów poznawczych sprzyja korzystaniu z ukierunkowań nauczyciela oraz pozwala na samodzielne podejmowanie i rozwiązywanie zadań. W efekcie uczeń zdobywa rozmaite kompetencje, zarówno akademickie, jak i praktyczne. Posiadanie wielu różnych kompetencji stanowi podstawę kształtowania się takich cech jak przedsiębiorczość i pracowitość (Erikson, 1997), sprzyja zdobywaniu nowych informacji i przeciwdziała kształtowaniu osoby konformistycznej (Bruner, 2006).

Jedną z ważnych kompetencji, którą powinien zdobyć uczeń w młodszym wieku szkolnym, jest umiejętność uczenia się, na co zwraca uwagę Bruner (2006), a co wyraża się między innymi w świadomym organizowaniu materiału. Początkowo uczeń dokonuje takich operacji pod kierunkiem nauczyciela, a z czasem, poznając sposoby organizowania materiału, takie jak klasyfikowanie, porównywanie, zmienianie struktury, próbuje czynić to samodzielnie. Wyniki prezentowanych badań nad umiejętnością operowania wiedzą pokazały, że wiedza uczniów korzystających z edukacji domowej była bardziej uporządkowana, na co wskazywała 
umiejętność dostrzegania i językowego wyrażania relacji między kategoriami nadrzędnymi i podrzędnymi, a co przejawiało się w podawaniu pełnych, ustrukturowanych definicji. Natomiast uczniowie edukacji szkolnej dostrzegali i przekazywali pojedyncze informacje szczegółowe dotyczące cech opisywanych zjawisk lub też wskazywali jedynie na kategorię nadrzędną, ale nie potrafili ustalić relacji między tymi dwoma rodzajami informacji. Za Stefanem Szumanem (1938) można powiedzieć, że tego rodzaju określenia definicyjne, informujące o braku strukturalizowania posiadanych informacji, wskazywałyby na niedostatek myślenia porządkującego. Uzyskane wyniki można by interpretować z punktu widzenia konstruowania wiedzy o świecie. Prawdopodobnie obie grupy badanych uczniów znają podobne informacje na temat różnych zjawisk, ale w odmienny sposób zapisały je w swojej reprezentacji poznawczej. Wypowiedzi uczniów edukacji domowej wskazują, że w ich reprezentacji poznawczej informacje zostały uporządkowane hierarchicznie, co byłoby dobrym predyktorem tworzenia pojęć na kolejnych etapach rozwoju.

Przejawem posiadania zorganizowanej wiedzy była także znajomość synonimicznych odpowiedników prezentowanych słów oraz ich nazw antonimicznych. Istotne różnice między badanymi grupami zaznaczyły się w odniesieniu do obu kategorii nazw, zwłaszcza w odniesieniu do antonimów. Uczniowie obu badanych grup mieli trudności z odnajdywaniem nazw przeciwstawnych znaczeniowo. Uzyskany wynik pozostaje w pewnej niezgodności z ogólną prawidłowością dotyczącą łatwości w opanowaniu antonimów, a ograniczeniem w znajomości i posługiwaniu się synonimami. Zgodnie z prawidłowością rozwojową dzieci wcześniej nabywają umiejętność różnicowania, wyrażającą się w szeregowaniu, niż umiejętność wykrywania podobieństw, stanowiącą podstawę czynności klasyfikowania (Piaget, Inhelder, 1967, 1993). Być może dla badanych uczniów poszukiwanie informacji drogą wykrywania podobieństw było ciekawym zadaniem, a być może często stosowanym przez nich sposobem porządkowania wiedzy o świecie, wywoływanym przez zadania ukierunkowujące (np. znajdź taki sam; do czego jest podobne itp.). Ponadto być może zaznaczająca się w edukacji szkolnej tendencja, by robić „tak samo”, sprzyja wykrywaniu podobieństw. Wykrywanie różnic, chociaż trudne dla wszystkich badanych, okazało się czynnością łatwiejszą dla uczniów edukacji domowej, co może wskazywać na plastyczność ich myślenia i otwartość na wyszukiwanie odmienności. Być może czynnikiem sprzyjającym poznawaniu słów i ich znaczeń przez dzieci edukacji domowej było używanie przez ich matki języka na zaawansowanym poziomie (Harding, Farrell, 2003), posługiwanie się kodem rozwiniętym w komunikowaniu się z dzieckiem (Bernstein, 1990). Warto także zaznaczyć, że proces opanowywania znaczeń wiąże się z budowaniem sieci semantycznych (Barrett, 1978, 1983), w których powinny występować przykłady o cechach kontrastywnych (pozytywnych i negatywnych). Opanowanie przeciwstawnych elementów w sieci semantycznej stanowi podstawę dalszego różnicowania znaczeń. Być może dzieci edukacji domowej będą do wykonywania tej operacji lepiej przygotowane.

Przejawem posiadania wiedzy, którą nie tylko się zapamiętało, ale także się rozumie, były odpowiedzi na pytania dotyczące wykrywania relacji przyczynowo-skutkowych w prezentowanych tekstach. Okazało się, że uczniowie edukacji szkolnej częściej przywoływali w odpowiedzi dosłowne sformułowania zawarte w tekście, co wskazywałoby na ich skłonność do dosłownego zapamiętania tego, co poznają, bez myślowego opracowywania pozyskanych informacji. Odpowiedzi uczniów edukacji domowej dowodziłyby natomiast tendencji do opracowywania poznawanego materiału, do wykrywania relacji przyczynowo-skutkowych między informacjami zawartymi w tekście, a nie tylko do odtworzenia poznanego w tekście sformułowania. W badaniach nad rozumieniem tekstu Jenkins (1986) zwraca uwagę na znaczenie wskazówek ukierunkowujących nauczyciela, pokazujących uczniowi różne strategie uczenia się, takie jak powtarzanie, wielokrotne czytanie, stawianie pytań i poszukiwanie odpowiedzi. Nauczyciel dziecka w późnym dzieciństwie powinien pokazywać różne strategie uczenia się, które staną się dla ucznia narzędziem przyswajania wiedzy. Uzy- 
skane przez nas wyniki wskazywałyby na brak dysponowania takimi narzędziami jak strategie uczenia się przez badanych uczniów edukacji szkolnej. Być może uczniowie edukacji domowej, nie korzystając z ukierunkowania przez edukatora, sami odkrywają strategie umożliwiające rozwiązanie zadania, polegające na analizowaniu relacji łączących przedstawione w tekście informacje. Taki sposób rozwiązywania zadań przez dzieci korzystające $\mathrm{z}$ edukacji domowej wskazywałby, że przejmują one inicjatywę, wychodzą poza znane interpretacje rzeczywistości, a co za tym idzie - stają się gotowe na przyjmowanie zmian (Bruner, 2006).

Analiza uzyskanych wyników dotyczących umiejętności operowania wiedzą w celu zrozumienia czytanego tekstu skłania do sformułowania prawdopodobnego wniosku, że edukacja domowa sprzyja opanowywaniu kompetencji uczenia się, dzięki czemu uczeń potrafi czytać tekst ze zrozumieniem. Wykorzystując posiadaną wiedzę, dostrzega różne relacje między informacjami, takie jak podobieństwo, przeciwstawność, nadrzędność, podrzędność, przyczyna, skutek, a to stanowi podstawę do adekwatnego odczytania informacji zawartych w tekście. Wyniki badań kanadyjskich (Martin-Chang, Gould, Meuse, 2011), dotyczących osiągnięć edukacyjnych młodszych uczniów (5-10 lat), pokazują, że edukacja domowa jest skuteczniejszą formą nauki niż edukacja szkolna. Zaletą tej edukacji są małe grupy, zindywidualizowane instrukcje, duża ilość czasu przeznaczonego na pisanie i czytanie. Prawdopodobnie takie uczenie, jakie charakterystyczne jest dla edukacji domowej, sprzyja opanowaniu uczenia się sensownego polegającego na uchwyceniu sensu i zapamiętaniu tego, co o nim stanowi, a nie przyswojeniu tekstu dosłownie (Włodarski, 1975). Dotychczasowe badania wykazały ponadto, że rodzice-edukatorzy częściej zaspokajają intelektualne i językowe potrzeby swoich dzieci oraz stawiają dzieciom więcej wymagań intelektualnych, a sami używają bardziej zaawansowanego języka (Tizard $\mathrm{i}$ in., 1982; Tizard, Hughes, 1984). Warto zauważyć, że nabycie umiejętności operowania wiedzą w późnym dzieciństwie stanowi dobrą podstawę do uczenia się na kolejnych etapach edukacji. Można przyjąć, że dzieci korzystające $\mathrm{z}$ edukacji domowej będą prawdopodobnie dobrze przygotowane do zdobywania wiedzy, rozumienia czytanych tekstów, organizowania informacji. Jak pisał Bruner (2006), uczenie ma także charakter intrapsychiczny, oddziałując na to, co dzieje się w umyśle ucznia.

Zadaniem każdego systemu edukacyjnego jest nie tylko dostarczanie wiedzy o świecie, wyposażenie umysłu dziecka w spostrzeżenia, wyobrażenia, pojęcia, ale także poddawanie ćwiczeniom jego czynności poznawczych. Przed laty Jean Piaget zauważył, że temu drugiemu celowi służą stosowane w edukacji metody aktywne, dzięki którym „operacje logiczne tworzą się i osiągają swoje struktury całościowe w zależności od pewnego treningu, nie tylko werbalnego, ale przede wszystkim związanego z rzeczywistym działaniem na przedmiotach i z eksperymentowaniem" (Piaget, 1977, s. 81).

Sprawdzeniu poziomu rozwoju funkcjonowania umysłu badanych dzieci służyło badanie wyższych funkcji poznawczych. Między badanymi grupami, zróżnicowanymi według kryterium systemu edukacyjnego, zaznaczyły się zarówno podobieństwa, jak i różnice. Okazało się, że zdolność hamowania narzucającej się reakcji, a także zdolność przewidywania działań prowadzących do osiągnięcia celu, są rozwinięte na podobnym poziomie u uczniów $\mathrm{z}$ obu badanych grup. W późnym dzieciństwie zwiększa się wyraźnie sprawność mechanizmów kontroli: uwaga staje się dowolna, selektywna i planowa, a także możliwa staje się adaptacja uwagi do zadania (Kołodziejczyk, 2011). Wymienione zmiany rozwojowe zachodzą, jak się okazało, u wszystkich dzieci na pewnym etapie rozwoju, niezależnie od warunków środowiskowych. Podobnie zdolność planowania kolejnych czynności prowadzących do osiągnięcia celu okazała się niewrażliwa na fakt zróżnicowanych edukacyjnie oddziaływań. Można by zatem zakładać, że rozwój omawianych funkcji poznawczych zależy raczej od ogólnych prawidłowości rozwojowych niż od środowiskowych uwarunkowań modyfikujących.

Natomiast modyfikujący wpływ systemu edukacyjnego dał się zauważyć w przypadku pamięci roboczej. Szkoła publiczna, stawiająca na zapamiętanie materiału nauczania, sprzyja 
ćwiczeniu pamięci. Stąd istotnie wyższe wyniki w zakresie pamięci roboczej uzyskali uczniowie edukacji publicznej w porównaniu z uczniami edukacji domowej. Pod wpływem stosowania w szkole takich metod, jak ,powtórzyć, aby zapamiętać”, oraz stawiania zadań polegających na odtwarzaniu zapamiętanego materiału doskonali się pamięć, czego efektem jest wzrost objętości pamięci oraz opanowanie strategii pamięciowych. W zindywidualizowanym nauczaniu, jakie występuje w edukacji domowej, ważne jest natomiast zainteresowanie ucznia tematem, pozostawienie czasu i dowolności w sposobie rozwiązywania zadań. Zgodnie $\mathrm{z}$ uwagami zawartymi $\mathrm{w}$ raporcie przygotowanym przez Botkina, Elmandjrę i Malitzę (1982) można przypuszczać, że szkoła nastawiona jest na zapamiętywanie przez ucznia podawanych informacji i ich utrwalanie, czemu służy uczenie zachowawcze. Ponadto szkoła nastawiona jest na ocenianie stopnia przyswojenia nauczanych treści przez ucznia (Bernstein, 1990), co również może sprzyjać ich dosłownemu zapamiętywaniu.

Uczniowie edukacji domowej uzyskali natomiast istotnie wyższe wyniki w pomiarze plastyczności poznawczej. Prawdopodobnie jest to efekt zindywidualizowanego nauczania prowadzonego przez rodziców, którzy dostosowują, prawdopodobnie intuicyjnie, sposoby nauczania do potrzeb swego dziecka, a ponadto pozostawiają mu możliwość dochodzenia do rozwiązania własną drogą. Na taką dowolność postępowania nie pozwala szkoła prowadząca zbiorowe nauczanie, niekiedy w dość dużych grupach, gdzie wszyscy rozwiązują takie same zadania, zgodnie z podanymi regułami i dochodzą do tego samego wyniku w tym samym czasie.

Analiza różnic między badanymi grupami uczniów w zakresie rozwoju wyższych procesów poznawczych prowadzi do refleksji na temat możliwości każdego z rozpatrywanych systemów edukacyjnych co do przygotowania ucznia do funkcjonowania w przyszłości. Zgodnie z postulatami prezentowanymi przez Brunera, Bernsteina, autorów Raportów Klubu Rzymskiego czy psychologów rozwoju, między innymi Eriksona, Piageta, Wygotskiego, należałoby przygotować ucznia, który potrafi adaptować się do nieznanych sytuacji, wypróbowywać znane strategie do nowych zadań, reagować na nowości przyjaznym zainteresowaniem. Z naszych badań wynika, że każdy z dwu rozważanych systemów edukacyjnych spełnia w pewnym zakresie to ogólne zadanie. Jednakże osiągnięcia uczniów edukacji domowej w zakresie umiejętności operowania wiedzą oraz plastyczności poznawczej, przewyższające wyniki uczniów edukacji szkolnej, stanowią podstawę do pozytywnych ocen edukacji domowej w postulowanym zakresie. Niestety wartość wyników prezentowanych badań jest ograniczona ze względów metodologicznych.

Warto zauważyć, że w wielu badaniach zostało potwierdzone, że znaczącym czynnikiem wpływającym na osiągnięcia ucznia jest postrzegany przez niego wysoki poziom zaangażowania rodziców (parent empowerment) w proces nauczania, zaś forma edukacji nie ma istotnego znaczenia (Barwegen i in., 2004). Na zaangażowanie rodziców składa się wiele działań, takich jak: pomoc, kontrola, wsparcie i uczestnictwo (Mau, 1997). Można przyjąć, że zaangażowanie rodziców w edukację dziecka, traktowanie uczenia się jako ważnego sposobu zdobywania wiedzy o świecie cechowało rodziców, którzy wybrali formę edukacji domowej. Należałoby zatem wskazać na potrzebę zmiany stosunku każdego z rodziców do edukacji dziecka i zaangażowania się w działalność edukacyjną. Przejawem takiego zaangażowania nie musi być podjęcie edukacji domowej, ale aktywne włączanie się $\mathrm{w}$ proces nauczania przebiegający w szkole.

Rodzice prowadzący edukację domową są często wspierani przez stowarzyszenia i organizacje społeczne akceptujące tę formę uczenia dzieci. W USA najbardziej znaną i najbardziej wpływową organizacją jest Home School Legal Defense Association (HSLDA) (Carlson, 2020). W Polsce działa między innymi Fundacja Edukacji Domowej oraz Centrum Nauczania Domowego, które zapewnia kompleksowe wsparcie edukacyjne i dydaktyczne w formie dostępu do Internetowej Platformy Edukacyjnej, w formie lekcji online z doświadczonym nauczycielem, scenariuszy zajęć lekcyjnych i repetytoriów, wsparcie przez nauczycieli i pedagogów, na- 
wiązanie przyjaźni z edukatorami domowymi z całej Polski. Naszym zdaniem niezmiernie ważna jest rola psychologów szkolnych, którzy powinni rozważyć opracowanie strategii udzielania pomocy rodzinom prowadzącym edukację domową.

W dyskusji nad skutecznością edukacji domowej w rozwijaniu różnych kompetencji dziecka należy powrócić do kwestii metodologicznych. $Z$ analizy prowadzonych dotąd badań wynika, że jest kilka czynników, które przeszkadzają w uzyskaniu jasnego obrazu osiągnięć edukacyjnych uczniów edukacji domowej, w tym niedociągnięcia metodologiczne. Są one trojakiego rodzaju. Po pierwsze, jak zaznaczałyśmy wcześniej, nie zawsze grupy uczniów edukacji domowej i edukacji szkolnej są równoważnie dobierane $\mathrm{z}$ uwzględnieniem wielu czynników środowiska domowego i lokalnego. Po drugie, w poszczególnych badaniach używane są różne zestawy prób, co utrudnia dokonywanie zestawień. Ponadto stosowane zadania mają niekiedy postać znanych i używanych testów (w naszych badaniach były to zadania programu komputerowego Inquisit), co stwarza możliwość analiz porównawczych. Niekiedy natomiast zadania są przygotowywane dla potrzeb określonego badania, jak w naszym przypadku Test Rozumienia Czytanego Tekstu, co nie tylko utrudnia prowadzenie analiz porównawczych, ale także ogranicza uogólnianie i odnoszenie uzyskanego efektu do innych grup dzieci korzystających z edukacji domowej. Po trzecie, do badań zwykle zgłaszają się osoby zainteresowane wykazaniem, że ich dziecko odznacza się wysokimi osiągnięciami w nauce; zwykle dotyczy to uczniów edukacji domowej. Zjawisko wycofywania się osób z badań i w efekcie ujmowania $\mathrm{w}$ opracowaniach jedynie wyników osób pozytywnie nastawionych do badań było rozważane z perspektywy zniekształcania uzyskiwanych wyników (por. Bradley, 1991).

W Polsce $\mathrm{z}$ edukacji domowej korzysta niewielka część uczniów, w większości z podstawowego poziomu kształcenia. Niewątpliwie potrzebne są badania ukazujące wartość tej formy edukacji i właśnie temu celowi mogą służyć wyniki przedstawionych w niniejszym artykule badań. Jednocześnie zdajemy sobie sprawę z ograniczonej wartości naszych badań ze względu na nieliczną grupę badanych uczniów, a także zakres eksplorowanych zagadnień. Nasze badania dotyczą jedynie poziomu rozwoju funkcji poznawczych uczniów oraz umiejętności operowania wiedzą. Nie sprawdzano osiągnięć szkolnych badanych uczniów. Nie prowadzono badań nakierowanych na rozpoznanie stosowanych przez nauczycieli i rodziców-edukatorów sposobów nauczania, nie sprawdzano kompetencji edukacyjnych osób prowadzących nauczanie, nie porównywano wiedzy rodziców uczniów badanych grup na temat edukacji ani też ich stosunku do szkoły.

Przedstawione w artykule badania dostarczają dowodów empirycznych w dyskusji nad rolą edukacji jako czynnika rozwoju w okresie edukacji elementarnej. W sytuacji, jaka zaistniała w systemie edukacji w związku z epidemią wywołaną wirusem COVID-19, warto wziąć pod uwagę możliwość skorzystania z takiej formy edukacji, jaką jest edukacja domowa. $\mathrm{Z}$ drugiej strony, opisane badania wpisują się w metodologiczne rozważania nad wartością pozyskiwanych w badaniach psychologicznych danych dotyczących rozwijających wartości edukacji domowej.

\section{PRZYPISY}

1 Ustawa o systemie oświaty, 7.02.1991, art. 16, ust. 8.

2 http://www.sejm.gov.pl/Sejm9.nsf/InterpelacjaTresc.xsp?key=BN79VL\&view=5.

3 W Polsce w roku 2017 z edukacji domowej korzystało 13955 uczniów.

$4 \mathrm{~W}$ przypadku wyników dotyczących elastyczności poznawczej rozkłady nie były normalne i wystąpił brak jednorodności wariancji. Do analizy wykorzystano test nieparametryczny (U Manna-Whitneya), a miarą wielkości efektu jest $r$ Glassa. 


\section{BIBLIOGRAFIA}

Anderson P., Anderson V., Lajoie G. (1996), The Tower of London test: Validation and standardization for pediatric populations. The Clinical Neuropsychologist, 10, 55-65.

Barrett M.D. (1978), Lexical development and overextension in child language. Journal of Child Language, 5(2), 205-219.

Barrett M.D. (1983), The early acquisition and development of the meanings of action-related words. In: T.B. Seiler, W. Wannenmacher (eds.), Concept development and the development of word meaning, 191-209. Berlin: Springer-Verlag.

Barwegen L.M., Falciani N.K., Putnam S.J., Reamer M.B., Stair E.E. (2004), Academic Achievement of Homeschool and Public School Students and Student Perception of Parent Involvement. School Community Journal, 14(1), 39-58.

Berg W.K., Byrd D.L. (2002), The Tower of London Spatial Problem Solving Task: Enhancing Clinical and Research Implementation. Journal of Experimental and Clinical Neuropsychology, 25, 586-604.

Bernstein B. (1990), Odtwarzanie kultury. Warszawa: Państwowy Instytut Wydawniczy.

Botkin J.W., Elmandjra M., Malitza M. (1982), Uczyć się - bez granic. Raport Klubu Rzymskiego. Warszawa: PWN.

Boulter L.T. (2017), A comparison of the academic achievement of home school and public school students. International Journal of Buisness and Social Research, 7(3), 1-9.

Bradley B.S. (1991), Infancy as paradise. Human Development, 34, 35-54.

Bruner J. (2006), Kultura edukacji. Kraków: Universitas.

Budajczak M. (2004), Edukacja domowa. Gdańsk: Gdańskie Wydawnictwo Psychologiczne.

Cagigas X.E., Filoteo J.V., Stricker J.L., Rilling L.M., Friedrich F.J. (2007), Flanker compatibility effects in patients with Parkinson's disease: Impact of target onset delay and trial-by-trial stimulus variation, Brain and Cognition, 63, 247-259.

Carlson J.F. (2020), Context and Regulation of Homeschooling: Issues, Evidence, and Assessment Practices. School Psychology, 35(1), 10-19.

Catsambis S. (1998), Expanding the knowledge of parent involvement in secondary education: Effects on high school academic success. (CRESPAR Tech. Rep. No. 27), Baltimore, MD: Johns Hopkins University.

Cianchetti C., Corona S., Foscoliano M., Comptu D., Sannio Fancello G. (2007), Modified Card Sorting Test: normative data in children 4-13 years old, according to classical and new types of scoring, The Clinical Neuropsychology, 21(3), 456-478.

Delors J. (red.), (1998), Edukacja: jest w niej ukryty skarb. Raport dla UNESCO Międzynarodowej Komisji do spraw Edukacji dla XXI wieku. Warszawa: Stowarzyszenie Oświatowców Polskich Wydawnictwa UNESCO.

Divoky D. (1983), The New Pioneers of the Home Schooling Movement. Phi Delta Kappan, 64(6), 395-398.

Doroszewski W. (red.), (1996), Stownik języka polskiego. Warszawa: PWN.

Eriksen B.A., Eriksen C.W. (1974), Effects of noise letters upon identification of a target letter in a nonsearch task. Perception \& Psychophysics, 16, 143-149.

Erikson E. (1997), Dzieciństwo i społeczeństwo. Poznań: Dom Wydawniczy Rebis.

Głowacka M. (2015), Edukacja domowa a przemiany nowoczesności. Zoon Politikon, 6, 219-236.

Hafer R. (2017), New estimates on the relationship between IQ, economic growth and welfare. Intelligence, $61,92-101$.

Harding T.J.A. (1997), Why Australian Christian Academy Families in Queensland Choose to Home School: Implications for Policy Development. Unpublished thesis, Queensland University of Technology; Brisbane, Queensland.

Harding T., Farrell A. (2003), Home schooling and legislated education. The Journal of the Australian and New Zealand Educational Law Association, 8, 127-136.

Hughes, C., (2011), Changes and challenges in 20 years of research into the development of executive functions, Infant and Child Development, 20(3), 251-271.

Hughes C., Graham A., Grayson A. (2004), Executive functions in childhood: development and disorder. W: J. Oates, A. Grayson (red.), Cognitive and language development in children. Oxford: Blackwell Publishing. 
Jenkins J.J. (1986), Funkcjonalne podejście do badań nad rozumieniem. W: I. Kurcz, J. Bobryk, D. Kądzielawa (red.), Wiedza a język. T. 1, Ogólna psychologia języka i neurolingwistyka, 15-35. Warszawa: Zakład Narodowy imienia Ossolińskich.

Jodzio K. (2008), Neuropsychologia intencjonalnego działania. Koncepcje funkcji wykonawczych. Warszawa: Wyd. Scholar.

Johnstone S.J., Galletta D. (2012), Event-rate effects in the flanker task: ERPs and task performance in children with and without AD/HD. International Journal of Psychophysiology, 87(3), 340-348.

Józefacka-Szram N. (2014), Diagnoza funkcji wykonawczych u dzieci. Psychiatria i Psychologia Kliniczna, 14(2), 116-121.

Kaczan R., Rycielski P., Wasilewska O. (2012), Wybrane uwarunkowania zadowolenia ze szkoły rodziców dzieci uczących się w szkołach podstawowych. Edukacja, 4(120), 84-99.

Kessels R.P.C., van Zandvoort M.J.E., Tostma A., Kappelle L.J., de Haan E.H.F. (2000), The Corsi Block Tapping task: Standarization and normative data. Applied Neuropsychology, 7(4), 252-258.

Kołodziejczyk A. (2011), Późne dzieciństwo - młodszy wiek szkolny. W: J. Trempała (red.), Psychologia rozwoju człowieka, 234-258. Warszawa: PWN.

Krikorian R., Bartok J., Gay N. (1994), Tower of London procedure: a standard method and developmental data. Journal of Clinical Experimental Neuropsychology, 16, 840-850.

Kupisiewicz C., Kupisiewicz M. (2009), Stownik pedagogiczny. Warszawa: PWN.

Lubienski Ch., Puckett T., Brewer T.J. (2013), Does Homeschooling "work"? A Critique of the Empirical Claims and Agenda of Advocacy Organizations. Peabody Journal of Education, 88, 378-392.

Mau W.C. (1997), Parental influences on the high school students' academic achievement: A comparison of Asian immigrants, Asian Americans, and White Americans. Psychology in the Schools, 34(3), 267-277.

Martin-Chang S., Gould O.N., Meuse R.F. (2011), The impact of schooling on academic achievement: evidence from homeschooled and traditionally schooled students. Canadian Journal of Behavioral Science, 43(3), 195-202.

Medlin R. (2013), Homeschooling and the question of socialization revised. Peabody Journal of Education, 88(3), 284-297.

Miyake A., Friedman N.P., Emerson M.J., Witzki A.H., Howerter A., Wager T.D. (2000), The unity and diversity of executive functions and their contributions to complex "frontal lobe" tasks: A latent variable analysis. Cognitive Psychology, 41, 49-100.

Piaget J. (1977), Dokad zmierza edukacja. Warszawa: PWN.

Piaget J., Inhelder B.(1967), Operacje umysłowe i ich rozwój. W: P. Fraisse, J. Piaget (red.), Inteligencja. Warszawa: PWN.

Piaget J., Inhelder B.(1993), Psychologia dziecka. Wrocław: Wydawnictwo Siedmiogród.

Pilch T. (2003), Encyklopedia pedagogiczna XXI wieku. Warszawa: Wydawnictwo Żak.

Pinker S. (2018), Nowe oświecenie. Argumenty za rozumem, nauka, humanizmem i postępem. Poznań: Wydawnictwo Zysk i S-ka.

Ray B.D. (1997), Strengths of their own homeschoolers across America: Academic achievements, family characteristics and longitudinal traits. Salem: NHERI.

Ray B.D. (2009), A review of research on homeschooling and what might educators learn? Salem: NHERI.

Ray B.D. (2010), Academic achievement and demographic traits of homeschool students: A nationwide study. Academic Leadership Journal, 8(1), 1-31.

Ray B.D. (2011), Historia, rozwój i filozofia edukacji domowej. W: J. Piskorski (red.), Szkoła domowa. Między wolnością a obowiązkiem, 19-25. Warszawa: Instytut Sobieskiego.

Rorty R. (1993), Edukacja i wyzwania postnowoczesności. W: Z. Kwieciński, L. Witkowski (red.), Spory o edukację. Dylematy i kontrowersje we współczesnych pedagogiach, 96-102. Warszawa: Edytor.

Rothermel P. (2004), Home-education: Comparison of home-and school-educated children on PIPS baseline assessments. Journal of Early childhood Research, 2(3), 273-299.

Rudner L.M. (1999), Scholastic Achievement and Demographic Characteristics of Home School Students in 1998. Education Policy Analysis Archives, 7, 8, 1-33.

Sacks P. (2007), Tearing down the gates: Confronting the class divide in American education. Los Angeles: University of California Press. 
Salthouse T.A. (2010), Is flanker-based inhibition related to age? Identifying specific influences of individual differences on neurocognitive variables. Brain and Cognition, 73, 51-61.

Schnirman G.M., Welsh M.C., Retzlaff P.D. (1998), Development of the Tower of London-Revised. Assessment, 5, 355-360.

Shallice T. (1982), Specific impairments of planning. Philosophical Transcripts of the Royal Society of London, B298, 199-209.

Shyers L.E. (1992), A comparison of social adjustment between home and traditionally schooled students. Home School Researcher, 8(3), 1-8.

Smedley T.C. (1992), Socialization of home school Children. Home School Researcher, 8(3), 9-16.

Smith Ch., Sikkink D. (1993), Is private schooling privatizing? First Things, 92, 16-20.

Szuman S. (1938), Rozwój myślenia u dzieci w wieku szkolnym. Lwów-Warszawa: Książnica Atlas.

Taylor J.W. (1986), Self-concept in home schooling children. Doctoral dissertation, Andrews University, Berrien Springs, MI.

Tillman V.D. (1995), Home schoolers, self-esteem, and socialization. Home school Researcher, 11(3), 1-6.

Tizard B., Hughes M. (1984), Young children learning. London: Fontana.

Tizard B., Hughes M., Pinkerton G., Carmichael H. (1982), Adults' Cognitive Demands at Home and at Nursery School. Journal of Child Psychology and Psychiatry, 23, 105-116.

Wenklar K. (2013), Edukacja domowa - pięć najczęściej stawianych pytań. Edukacja elementarna w teorii i praktyce, 4, 109-117.

West R.L. (2009), The harms of homeschooling. Philosophy \& Public Policy Quarterly, 29, 7-12.

White C.N., Ratcliff R., Starns J.J. (2011), Diffusion models of the flanker task: Discrete versus gradual attentional selection. Cognitive Psychology, 63, 210-238.

Włodarski Z. (1975), Rozwój i ksztaltowanie doświadczenia indywidualnego. Warszawa: Wydawnictwa Szkolne i Pedagogiczne.

Wrigley, T. (2011), Culture, class, and curriculum: A reflective essay. In: P.E. Jones (eds.), Marxism and education: Renewing the dialogue, pedagogy, and culture, 11-38. New York: Palgrave Macmillan.

Wygotski L.S. (1971a), Problem nauczania i rozwoju umysłowego w wieku szkolnym. W: L.S. Wygotski, Wybrane prace psychologiczne, 531-547. Warszawa: PWN.

Wygotski L.S. (1971b), Nauczanie a rozwój w wieku przedszkolnym. W: L.S. Wygotski, Wybrane prace psychologiczne, 517-530. Warszawa: PWN.

Zasieczny A. (red.). (1999), Wielka encyklopedia dla dzieci. Warszawa: MUZA. 